\begin{tabular}{c} 
Brazilian Journal \\
of Chemical \\
Engineering \\
\hline
\end{tabular}

ISSN 0104-6632

Printed in Brazil

www.abeq.org.br/bjche

Vol. 30, No. 03, pp. 657 - 665, July - September, 2013

\title{
ADSORPTION OF REMAZOL BRILLIANT BLUE ON AN ORANGE PEEL ADSORBENT
}

\author{
M. R. Mafra, L. Igarashi-Mafra*, D. R. Zuim, É. C. Vasques and M. A. Ferreira \\ Graduation Program of Food Engineering, Chemical Engineering Department, Federal University of Paraná, \\ Phone: + (55) (41) 3361-3189, PO Box 19011, Zip Code 81531-990, Curitiba - PR, Brazil. \\ *E-mail: luciana.igarashi@ufpr.br \\ E-mail: marcos.mafra@ufpr.br; erikacvas@yahoo.com.br; dianazuim@yahoo.com.br; mary540@msn.com
}

(Submitted: August 17, 2010 ; Revised: April 18, 2012 ; Accepted: September 8, 2012)

\begin{abstract}
A novel orange peel adsorbent developed from an agricultural waste material was characterised and utilised for the removal of Remazol Brilliant Blue from an artificial textile-dye effluent. The adsorption thermodynamics of this dye-adsorbent pair was studied in a series of equilibrium experiments. The time to reach equilibrium was $15 \mathrm{~h}$ for the concentration range of $30 \mathrm{mg} \mathrm{L}^{-1}$ to $250 \mathrm{mg} \mathrm{L}^{-1}$. The adsorption capacity decreased with increasing temperature, from $9.7 \mathrm{mg} \mathrm{L}^{-1}$ at $20{ }^{\circ} \mathrm{C}$ to $5.0 \mathrm{mg} \mathrm{L}^{-1}$ at $60{ }^{\circ} \mathrm{C}$. Both the Langmuir and Freundlich isotherm models fitted the adsorption data quite reasonably. The thermodynamic analysis of dye adsorption onto the orange peel adsorbent indicated its endothermic and spontaneous nature. Thus, the application of orange peel adsorbent for the removal of dye from a synthetic textile effluent was successfully demonstrated.

Keywords: Orange peel; Adsorption; Dye; Kinetics; Thermodynamics; Wastewater.
\end{abstract}

\section{INTRODUCTION}

Wastewaters from the food colouring, paper, carpet, rubber, plastics, cosmetics and textile industries are polluted by dyes (Namasivayam et al., 1996; Crini, 2006; Azhar et al., 2005). The presence of very low concentrations of dyes in these effluents (less than $1 \mathrm{ppm}$ for some dyes) is highly visible and undesirable (Crini, 2006; Nigan et al., 2000). Colour affects the nature of the water and inhibits the penetration of sunlight into the receiving water bodies, which has a deleterious effect on photosynthesis and thus aquatic life (Arami et al., 2005; Gómez et al., 2007). Some dyes are also carcinogenic and mutagenic (Namasivayam and Kavitha, 2002).

There are many chemical varieties of dyes, e.g., acidic, basic and dispersed, with structures such as azo-, diazo- and anthraquinone-based and metalcomplex dyes. The highest rates of toxicity have been found amongst the basic and diazo direct dyes (Robinson et al., 2001).

The removal of dyestuffs from effluents is of great importance in many countries worldwide for both environmental and water reuse concerns (Choy et al., 1999). Due to the low biodegradability of dyes, conventional biological treatment processes are not very effective in treating dye wastewaters; therefore, they are usually treated by either physical or chemical processes (Azhar et al., 2005).

Activated carbon is the most widely used physicochemical treatment for the removal of dissolved organics from wastewater, effective even in dilute solution, but commercially available activated carbon is very expensive (Azhar et al., 2005; Namasivayam and Kavitha, 2002; Robinson et al., 2001). In order to decrease the treatment cost of dye removal, attempts have been made to find inexpensive and biodegradable alternative adsorbents

*To whom correspondence should be addressed 
(Namasivayam et al., 1996; Azhar et al., 2005; Namasivayam and Kavitha, 2002; Basava Rao and Ram Mohan Rao, 2006). In general, a sorbent can be assumed to be inexpensive if it requires little processing, is abundant in nature or is a by-product or waste material from another industry (Bailey et al., 1999).

Orange peel is an agro/industrial waste residue of the orange-juice and soft-drink industries all over the world (Namasivayam et al., 1996) and has been used to remove a number of dyes such as Direct Blue 86 (El Nemr et al., 2009), Direct N Blue-106 (Khaled et al., 2009a), Direct Yellow 12 (Khaled et al., $2009^{\mathrm{b}}$ ), Direct Red 23 and Direct Red 80 (Arami et al., 2005), Acid Violet 17 (Sivaraj et al.; 2001) and methyl orange, methylene blue, Rhodamine B, Congo red, methyl violet and amido black 10B (Annadurai et al., 2002).

Oranges are cultivated on a large scale in Brazil where they are of significant agronomic importance as the fruits are used both fresh and in the juice industry. Brazil is the largest orange-juice producer in the world so there is a need to find a use for the by-products of this industrial activity. In this work, orange peel was used as a low-cost adsorbent to remove the azo dye Remazol Brilliant Blue from aqueous solution. Kinetic and thermodynamic studies, the basic requirements for the design of adsorption systems, were conducted to evaluate its adsorption capacity.

\section{MATERIALS AND METHODS}

\section{Chemicals and Materials}

In order to obtain the orange peel adsorbent (OPA), fresh orange peel (orange exocarp and mesocarp), from Pêra sweet orange (Citrus sinensis (L.) Osbeck), was washed and cut into small pieces, dried in an oven at $60{ }^{\circ} \mathrm{C}$ for $24 \mathrm{~h}$ and crushed. The powdered orange peel was washed with hot water and dried in an oven at $60{ }^{\circ} \mathrm{C}$ for $12 \mathrm{~h}$. After drying they were sieved and used as an adsorbent. The dye Remazol Brilliant Blue R, an anthraquinone dye, was obtained from Acros Organics. The chemical structure of this dye is shown in Fig. 1.

\section{Characterisation of the Adsorbent}

The surface of the orange peel adsorbent was imaged by a scanning electron microscope (SEM, Shimadzu SS 550). The chemical composition of the adsorbent was analysed by X-ray fluorescence (XRF) using a Philips Analytical fluorescence system (PW $2400 / 00)$. The X-ray diffraction (XRD) pattern of the material was recorded in the range $2 \theta=3$ at $70^{\circ}$, in a Philips Analytical diffractometer (PW-1830) with a $\mathrm{Cu}$ anode. The diffractometer was operated at $40 \mathrm{~mA}$ and $40 \mathrm{KW}$ and the spectrum was recorded at a scanning speed of $2 \% \mathrm{~min}$. FTIR (Fourier Transform Infrared Spectroscopy) of the adsorbent was performed in an Excalibur Bio-Rad interferometer FTS 3500 GX model over the range of $4,000-400 \mathrm{~cm}^{-1}$ (32 scans). The adsorbent was dried under vacuum and $2 \mathrm{mg}$ of adsorbent was powdered and mixed with $300 \mathrm{mg}$ of anhydrous $\mathrm{KBr}$. The mixture was subjected to an 8-ton hydraulic press to obtain the pellets.

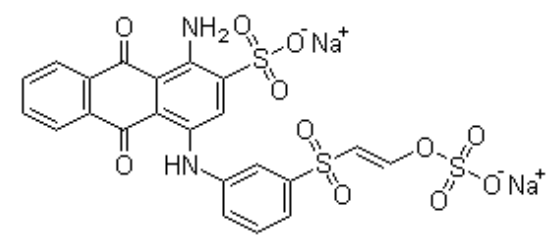

Figure 1: Chemical structure of Remazol Brilliant Blue R.

\section{Adsorption Procedure}

Batch adsorption experiments were carried out in a temperature-controlled orbital shaker (Tecnal TE-421) at a constant speed of $150 \mathrm{rpm}$. For all tests, $30 \mathrm{~mL}$ of dye solution were placed into a $125 \mathrm{~mL}$ conical flask with $300 \mathrm{mg}$ of orange peel adsorbent. The equilibrium time of adsorption was determined by analysing adsorptive uptake of the dye solution (30 $\mathrm{mg} \mathrm{L}^{-1}, 100 \mathrm{mg} \mathrm{L}^{-1}$ and $250 \mathrm{mg} \mathrm{L}^{-1}$ ) at different time intervals and temperatures of $20 \pm 0.2{ }^{\circ} \mathrm{C}$ and $60 \pm 0.2{ }^{\circ} \mathrm{C}$. To obtain the adsorption isotherms, dye solutions of different mass concentrations $\left(20 \mathrm{mg} \mathrm{L}^{-1}\right.$ to $350 \mathrm{mg} \mathrm{L}^{-1}$ ) were agitated with the adsorbent until equilibrium was achieved $(24 \mathrm{~h})$ at temperatures of $20{ }^{\circ} \mathrm{C}, 30^{\circ} \mathrm{C}, 40{ }^{\circ} \mathrm{C}, 50{ }^{\circ} \mathrm{C}$ and $60{ }^{\circ} \mathrm{C}$. After the experiments, the samples were filtered through quantitative filter papers (J. Prolab ${ }^{\circledR}$ white ribbon filter) and the equilibrium solution dye concentration was determined using an Ultraviolet-Visible (UV-VIS) spectrophotometer at $590 \mathrm{~nm}$. The amount of dye adsorbed onto the orange peel adsorbent at time $t, q_{t}$ $\left(\mathrm{mg} \mathrm{g}^{-1}\right)$, and at equilibrium, $\mathrm{q}_{\mathrm{e}}\left(\mathrm{mg} \mathrm{g}^{-1}\right)$, were obtained by mass balance, according to Equations (1) and (2). All experiments were performed in triplicate.

$q_{t}=\frac{V \cdot\left(C_{o}-C_{t}\right)}{W}$ 
$\mathrm{q}_{\mathrm{e}}=\frac{\mathrm{V} \cdot\left(\mathrm{C}_{\mathrm{o}}-\mathrm{C}_{\mathrm{e}}\right)}{\mathrm{W}}$

where $\mathrm{V}(\mathrm{L})$ is the solution volume, $\mathrm{C}_{\mathrm{o}}$ is the initial concentration of dye in $\mathrm{mg} \mathrm{L}^{-1}, \mathrm{C}_{\mathrm{t}}\left(\mathrm{mg} \mathrm{L}^{-1}\right)$ is the liquid-phase concentration of dye at time $\mathrm{t}(\mathrm{min}), \mathrm{C}_{\mathrm{e}}$ $\left(\mathrm{mg} \mathrm{L} \mathrm{L}^{-1}\right.$ ) is the equilibrium concentration of dye and $\mathrm{W}(\mathrm{g})$ is the weight of the adsorbent.

\section{RESULTS AND DISCUSSION}

\section{Characterisation of the Adsorbent}

The particle-size distribution of the adsorbent was determined as fractions in the ranges of $>1,180 \mu \mathrm{m}$ (0.70\%), 1,180-355 $\mu \mathrm{m} \quad(80.46 \%), 355-180 \mu \mathrm{m}$ (13.92\%), 90-63 $\mu \mathrm{m}(0.47 \%)$ and $<44 \mu \mathrm{m}(0.48 \%)$.

The SEM images (Fig. 2) showed the highly heterogeneous porous structure of the orange peel particles. Arami et al. (2005) also observed the same characteristic in orange peel adsorbent.

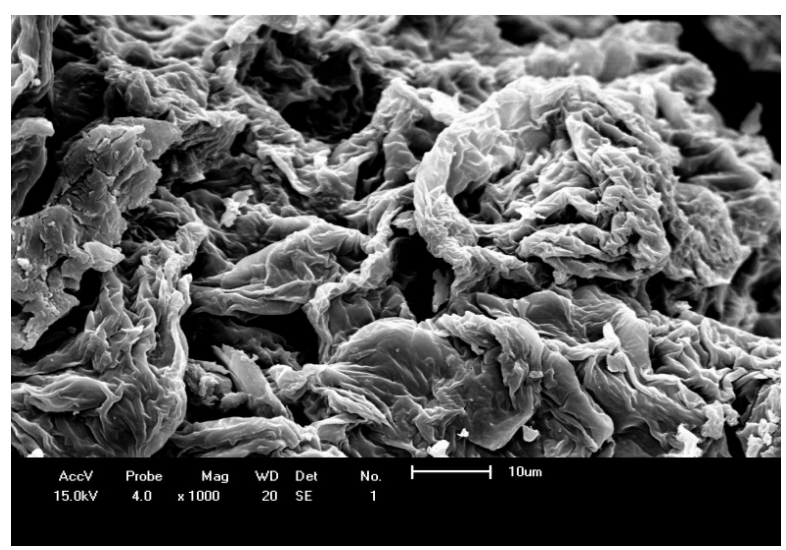

Figure 2: SEM image of orange peel adsorbent.

The chemical composition of the orange peel adsorbent as determined by X-ray fluorescence is shown in Table 1. The organic matter accounted for $97.83 \%$ of the chemical composition, which is expected for a vegetable tissue. Calcium content $(1.42 \%)$ was higher than the other minerals.

The X-ray diffraction spectrum (Figure 3) did not exhibit well-defined peaks in any region, which indicated that no discrete mineral phase was detected. Thus, the orange peel has a completely amorphous structure, which is expected for organic materials. The database used for mineralogical interpretation in this analysis was JCPDS (Joint
Committee on Powder Diffraction Standards) from the PHILIPS X'Pert HighScore software.

Table 1: Chemical composition of the OPA by $\mathrm{X}$-ray fluorescence analysis.

\begin{tabular}{|c|c|}
\hline Characteristic & Values \\
\hline $\mathrm{CaO}$ & $1.42 \%$ \\
$\mathrm{~K}_{2} \mathrm{O}$ & $0.18 \%$ \\
$\mathrm{SO}_{3}$ & $0.14 \%$ \\
$\mathrm{MgO}$ & $0.12 \%$ \\
$\mathrm{Fe}_{2} \mathrm{O}_{3}$ & $0.11 \%$ \\
$\mathrm{SiO}_{2}$ & $0.08 \%$ \\
$\mathrm{P}_{2} \mathrm{O}_{5}$ & $0.05 \%$ \\
$\mathrm{BaO}$ & $0.02 \%$ \\
$\mathrm{SrO}$ & $0.01 \%$ \\
$\mathrm{Al}_{2} \mathrm{O}_{3}$ & $0.01 \%$ \\
$\mathrm{NiO}_{\mathrm{WO}}$ & $0.01 \%$ \\
$\mathrm{ZnO}$ & not detected \\
$\mathrm{Mn}$ & not detected \\
Organic matter & not detected \\
\hline
\end{tabular}

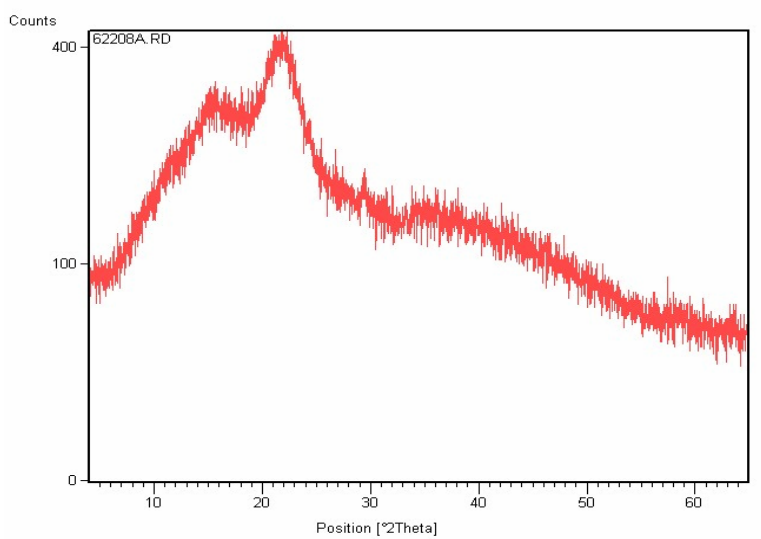

Figure 3: X-ray diffraction spectrum of orange peel adsorbent.

The FTIR spectrum of the orange peel is shown in Figure 4, displaying a number of adsorption peaks indicating the complex nature of the material examined. The broad, intense absorption peaks around $3,434 \mathrm{~cm}^{-1}$ are indicative of the absorption of water molecules, resulting from the $\mathrm{O}-\mathrm{H}$ stretching mode of hydroxyl groups characteristic of adsorbed water, while the bands at $2,924 \mathrm{~cm}^{-1}$ and $2,850 \mathrm{~cm}^{-1}$ were attributed to $\mathrm{C}-\mathrm{H}$ interactions with the surface of the adsorbent (Al-Qodah and Shawabkah, 2009). The bands in the range of 3,200-3,650 $\mathrm{cm}^{-1}$ have been attributed to the hydrogen-bonded -OH group of alcohols and phenols (Yang and Lua, 2003). The peak around $1,635 \mathrm{~cm}^{-1}$ is due to the $\mathrm{C}=\mathrm{C}$ stretching that can be attributed to the aromatic $\mathrm{C}-\mathrm{C}$ bond, and 


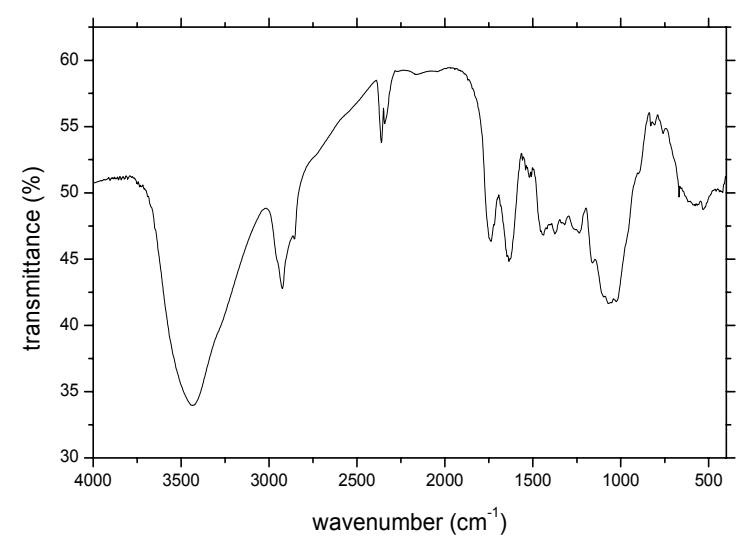

Figure 4: FTIR spectrum of orange peel adsorbent in $\mathrm{KBr}$ pellets.

the peak at $1,072 \mathrm{~cm}^{-1}$ can also be associated with either $\mathrm{C}-\mathrm{O}$ symmetric or asymmetric stretching vibration (-C-O-C- ring) (Khaled et al., 2009'; Khaled et al., $2009^{\mathrm{b}}$ ). The peaks at the region of 2,300-2,400 $\mathrm{cm}^{-1}$ indicated the carbon dioxide of normal air (Kalsi, 2004).

\section{Equilibrium Time of Adsorption}

The influence of contact time at $20^{\circ} \mathrm{C}$ and $60{ }^{\circ} \mathrm{C}$ on the amount of dye adsorbed per unit mass of orange peel $\left(\mathrm{q}_{\mathrm{t}}\right)$ is presented in Figures 5 and 6, respectively, showing the efficient adsorption of dye from wastewater. The uptake of dye by the adsorbent increased with initial dye concentration and decreased with temperature. The removal of dye was rapid in the initial stage of contact and gradually decreased with time until equilibrium was reached (Sivaraj et al., 2001). The time profiles of dye uptake were single, smooth and continuous curves leading to saturation, suggesting the possible monolayer coverage of dyes on the surface of the adsorbent (Malik, 2004). The contact time required to attain equilibrium was around $15 \mathrm{~h}$ for the three initial concentrations of dye studied.

Figures 5 and 6 show that the amount of dye adsorbed per unit mass of orange peel increased with increasing initial dye concentration. For a dilute concentration $\left(30 \mathrm{mg} \mathrm{L}^{-1}\right)$ the amount of dye adsorbed per unit mass of orange peel was $2.2 \mathrm{mg} \mathrm{g}^{-1}\left(20^{\circ} \mathrm{C}\right)$ and $1.7 \mathrm{mg} \mathrm{g}^{-1}\left(60{ }^{\circ} \mathrm{C}\right)$. In the case of the concentrated solution $\left(250 \mathrm{mg} \mathrm{L}^{-1}\right)$ an increase to $8.7 \mathrm{mg} \mathrm{g}^{-1}$ $\left(20{ }^{\circ} \mathrm{C}\right)$ and $4.7 \mathrm{mg} \mathrm{g}^{-1}\left(60{ }^{\circ} \mathrm{C}\right)$ was observed, meaning that the adsorption process was highly dependent on the initial dye concentration (Khaled et al., 2009 ; Rao and Rao, 2006).

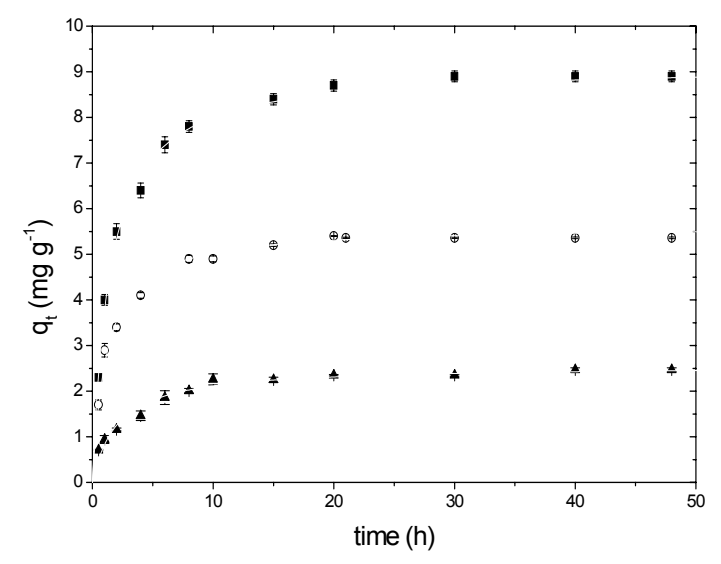

Figure 5: Effect of initial dye concentration and agitation time on adsorption by waste orange peel at $20^{\circ} \mathrm{C}$; (ム) $30 \mathrm{mg} \mathrm{L}^{-1}$, (०) $100 \mathrm{mg} \mathrm{L}^{-1}$, (•) $250 \mathrm{mg} \mathrm{L}^{-1}$

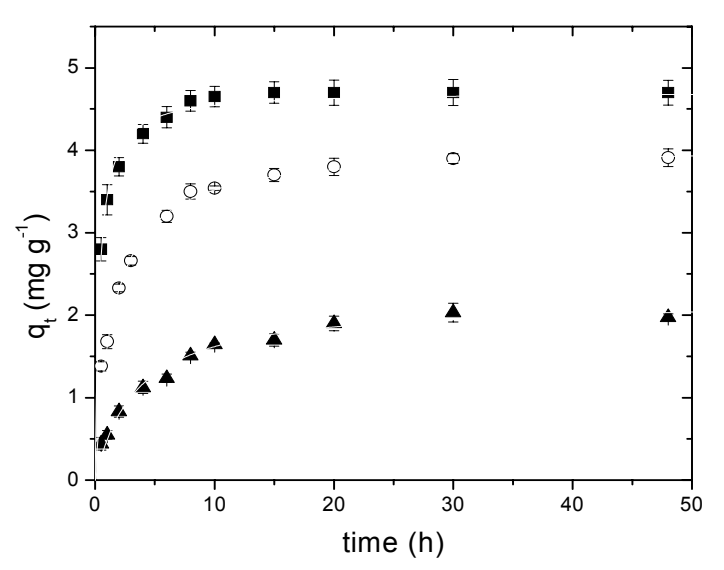

Figure 6: Effect of initial dye concentration and agitation time on adsorption by waste orange peel at $60{ }^{\circ} \mathrm{C}$; (ム) $30 \mathrm{mg} \mathrm{L}^{-1}$, (०) $100 \mathrm{mg} \mathrm{L}^{-1}$, (•) $250 \mathrm{mg} \mathrm{L}^{-1}$

\section{Adsorption Isotherm Studies}

The equilibrium measurements were focused on the determination of the adsorption isotherms. Figure 7 shows the relationship between the amounts of adsorbed dye per unit mass of the orange peel adsorbent $\left(\mathrm{q}_{\mathrm{e}}\right)$ and the equilibrium solution dye concentration $\left(\mathrm{C}_{\mathrm{e}}\right)$ for the temperature range of $20-60{ }^{\circ} \mathrm{C}$.

It was found that the adsorption capacity decreased as the temperature was increased from $20{ }^{\circ} \mathrm{C}$ to $60^{\circ} \mathrm{C}$ (Figure 7). According to Rao and Rao (2006) the reason for the fall in the adsorption capacity at elevated temperatures may be that at higher temperatures a part of the dye leaves the solid phase and re-enters the liquid phase. 


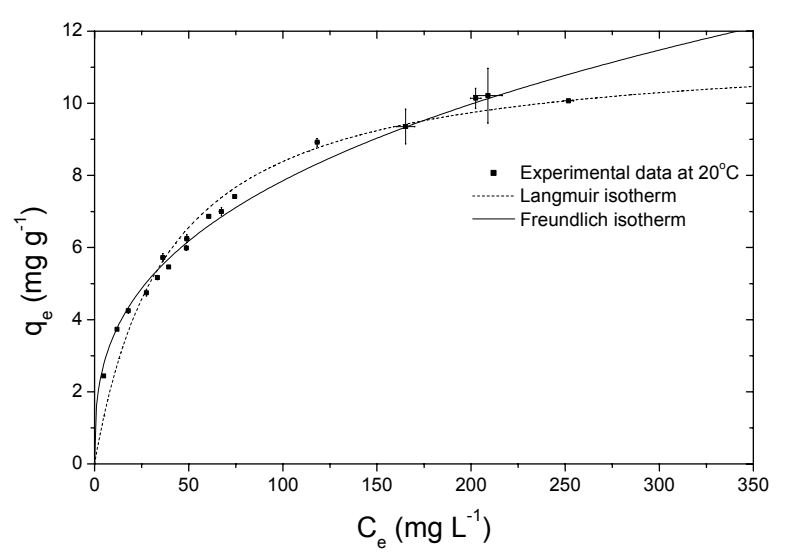

(a)

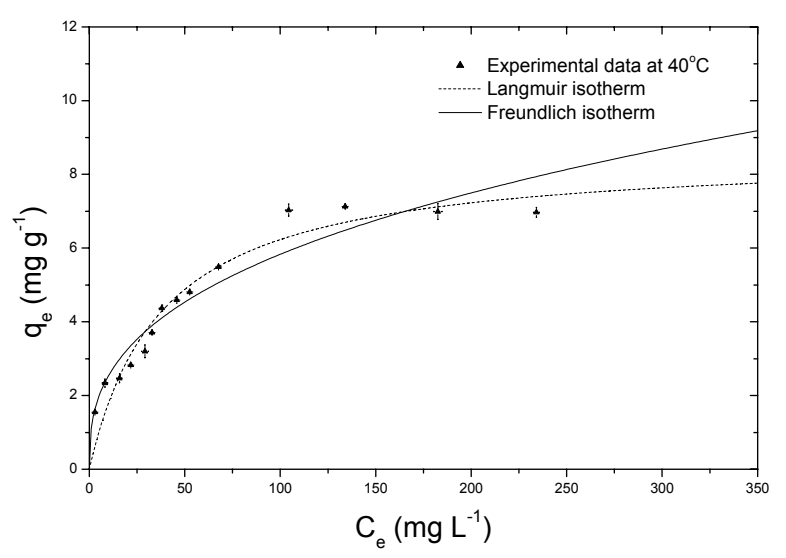

(c)

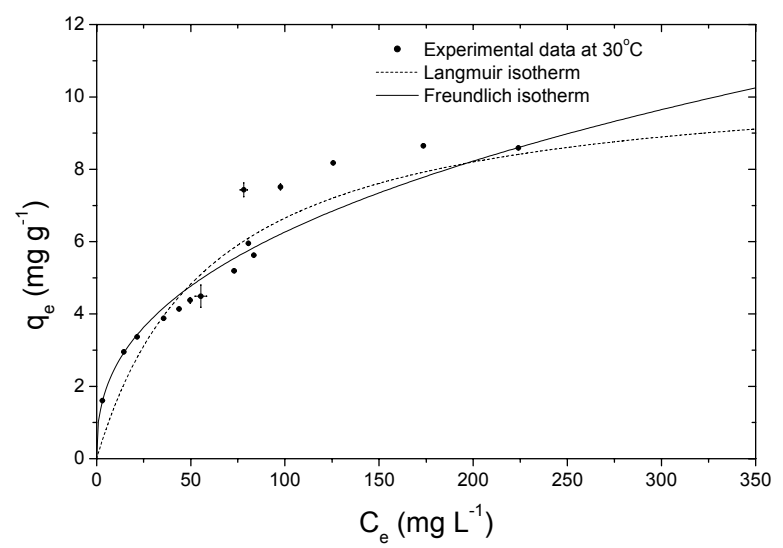

(b)

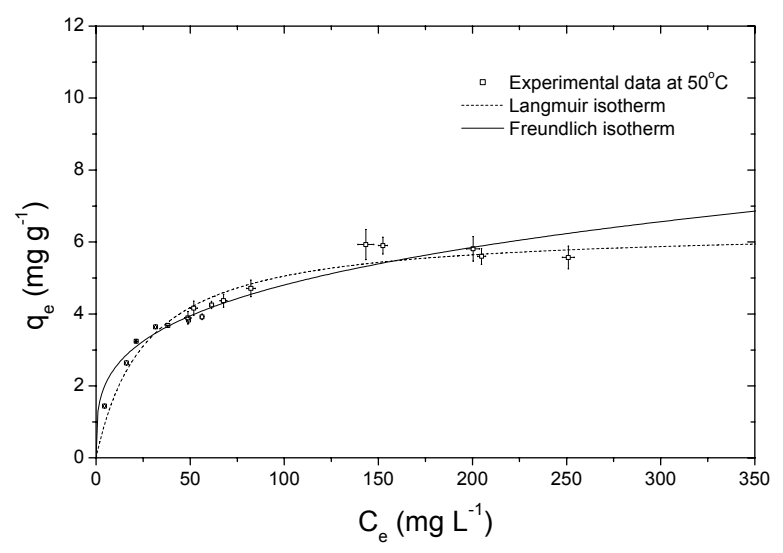

(d)

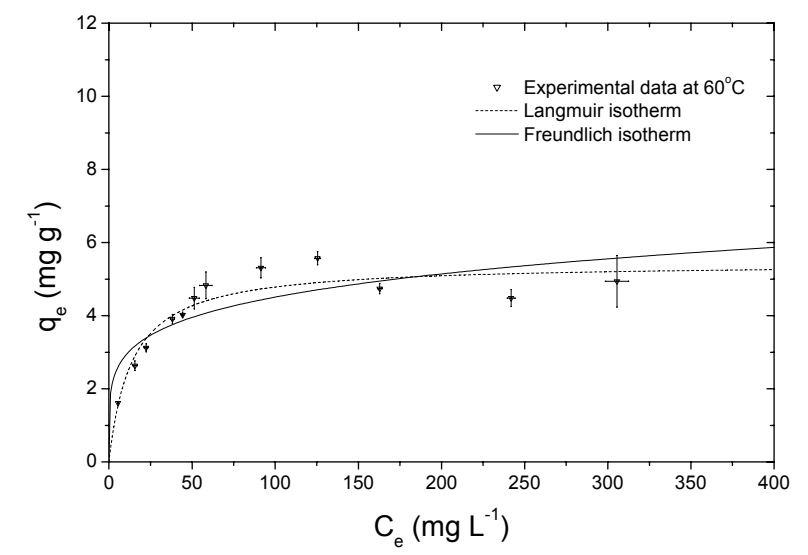

(e)

Figure 7: Isotherms for adsorption of Remazol Brilliant Blue R on orange peel adsorbent. Experimental conditions: contact time $24 \mathrm{~h}$; agitation $150 \mathrm{rpm}$; temperature (a) $20^{\circ} \mathrm{C}$, (b) $30{ }^{\circ} \mathrm{C}$, (c) $40{ }^{\circ} \mathrm{C}$, (d) $50{ }^{\circ} \mathrm{C}$ and (e) $60^{\circ} \mathrm{C}$.

Isotherm data should be accurately fit to a suitable isotherm model to find adsorption parameters that can be used in a design process (Khaled et al., 2009 $9^{\mathrm{a}}$. There are several isotherm equations available for analysing experimental sorption equilibrium data in single-solute systems. The most widely used are the Langmuir and Freundlich models. 
The non-linear Langmuir and Freundlich isotherms are represented by Equations (5) and (6), respectively:

$\mathrm{q}_{\mathrm{e}}=\frac{\mathrm{q}_{\max } \mathrm{K}_{\mathrm{L}} \mathrm{C}_{\mathrm{e}}}{1+\mathrm{K}_{\mathrm{L}} \mathrm{C}_{\mathrm{e}}}$

$\mathrm{q}_{\mathrm{e}}=\mathrm{K}_{\mathrm{F}} \mathrm{C}_{\mathrm{e}}^{1 / \mathrm{n}}$

where $\mathrm{q}_{\mathrm{e}}\left(\mathrm{mg} \mathrm{g}^{-1}\right)$ is the amount of dye adsorbed at equilibrium, $\mathrm{C}_{\mathrm{e}}\left(\mathrm{mg} \mathrm{L}^{-1}\right)$ is the equilibrium liquidphase dye concentration, $\mathrm{K}_{\mathrm{L}}\left(\mathrm{L} \mathrm{mg}^{-1}\right)$ is the Langmuir constant related to the apparent energy of adsorption, $\mathrm{K}_{\mathrm{F}}\left(\left(\mathrm{mg} \mathrm{g}^{-1}\right)\left(\mathrm{L} \mathrm{mg}^{-1}\right)^{1 / n}\right)$ is the Freundlich constant related to the distribution coefficient, $\mathrm{q}_{\max }$ is the maximum amount of adsorption corresponding to complete monolayer coverage on the surface $\left(\mathrm{mg} \mathrm{g}^{-1}\right)$ and $\mathrm{n}$ is a measure of the deviation from linearity of an adsorption.

The essential characteristics of a Langmuir isotherm can also be expressed in terms of a dimensionless constant-separation factor, $\mathrm{R}_{\mathrm{L}}$, given by Equation (7).

$$
\mathrm{R}_{\mathrm{L}}=\frac{1}{1+\mathrm{K}_{\mathrm{L}} \mathrm{C}_{\mathrm{o}}}
$$

where $\mathrm{C}_{\mathrm{o}}$ is the initial dye concentration $\left(\mathrm{mg} \mathrm{L}^{-1}\right)$. The $R_{L}$ value indicates the shape of the isotherm and hence the type of adsorption: irreversible $\left(\mathrm{R}_{\mathrm{L}}=0\right)$, favourable $\left(0<\mathrm{R}_{\mathrm{L}}<1\right)$, linear $\left(\mathrm{R}_{\mathrm{L}}=1\right)$ or unfavourable $\left(\mathrm{R}_{\mathrm{L}}>1\right)$ (Magdya and Daifullah, 1998).

The isotherm parameters and the coefficients of determination $\left(\mathrm{R}^{2}\right)$ (Table 2) were obtained by nonlinear least square regression analysis at a $95 \%$ confidence interval using StatSoft ${ }^{\circledR}$ STATISTICA software (version 7.0). The chi-square $\left(\chi^{2}\right)$ and standard deviation (SD) (Table 2) were obtained to determine the validity of the models and to reproduce experimental data.

The maximum adsorption capacity of the adsorbent for the dye (i.e., the $\mathrm{q}_{\max }$ value in the Langmuir equation) decreased from $11.62 \mathrm{mg} \mathrm{g}^{-1}$ to $5.44 \mathrm{mg} \mathrm{g}^{-1}$ with the increase in temperature from $20^{\circ} \mathrm{C}$ to $60{ }^{\circ} \mathrm{C}$. Otherwise, the Langmuir constant $\left(\mathrm{K}_{\mathrm{L}}\right)$ increased with increasing temperature, indicating that the adsorption process was endothermic. The $\mathrm{K}_{\mathrm{L}}$ value decreased from $20^{\circ} \mathrm{C}$ to $30^{\circ} \mathrm{C}$, which may be explained by greater values of $\chi^{2}$ and SD in comparison to the data fitting at the others temperatures.

The $\mathrm{R}_{\mathrm{L}}$ values of $0.0259-0.0730$ calculated at different temperatures lie between 0 and 1.0, indicating a favourable adsorption.

The values of $\mathrm{n}$ (from the Freundlich equation) between 2.9 - 5.3 represent good adsorption of the dye on orange peel adsorbent (Agrawal and Sahu, 2006).

\section{Adsorption Thermodynamics}

The thermodynamic equilibrium constants $\left(\mathrm{K}_{\mathrm{c}}\right)$ of the dye adsorption onto the studied adsorbent were calculated from the intercept of the plots of $\ln \left(\mathrm{q}_{\mathrm{e}} / \mathrm{C}_{\mathrm{e}}\right)$ versus $\mathrm{q}_{\mathrm{e}}$ by extrapolating to $\mathrm{q}_{\mathrm{e}}=0$ (Khan and Singh, 1987, Lyubchik et al., 2000, Niwas et al., 2000, Chen et al., 2009). The $\mathrm{K}_{\mathrm{c}}$ values increased with increasing temperature (Table 3 ). This $K_{c}$ value was further used to calculate the thermodynamic parameters.

Table 2: Langmuir and Freundlich constants for adsorption of dye on orange peel adsorbent.

\begin{tabular}{|c|c|c|c|c|c|c|c|c|c|c|c|}
\hline \multirow[b]{2}{*}{ Conditions } & \multicolumn{6}{|c|}{ Langmuir isotherm } & \multicolumn{5}{|c|}{ Freundlich isotherm } \\
\hline & $\underset{\left(\mathrm{mg} \mathrm{g}^{-1}\right)}{q_{\max }}$ & $\begin{array}{c}\mathrm{K}_{\mathrm{L}} \\
\left(\mathrm{L} \mathrm{\textrm {mg } ^ { - 1 }}\right)\end{array}$ & $\mathbf{R}_{\mathbf{L}}$ & $\mathbf{R}^{2}$ & $\chi^{2}$ & SD & $\begin{array}{c}K_{F} \\
\left(\mathrm{mg} \mathrm{g}^{-1}\right)\left(\mathrm{L} \mathrm{mg}^{-1}\right)^{1 / n}\end{array}$ & n & $\mathbf{R}^{2}$ & $\chi^{2}$ & SD \\
\hline $20^{\circ} \mathrm{C}$ & 11.62 & 0.0259 & 0.099 & 0.9790 & 0.0655 & 0.4849 & 1.600 & 2.895 & 0.9919 & 0.0131 & 0.3013 \\
\hline $30^{\circ} \mathrm{C}$ & 10.70 & 0.0164 & 0.15 & 0.9573 & 0.1181 & 0.6396 & 1.024 & 2.543 & 0.9612 & 0.0527 & 0.6104 \\
\hline $40^{\circ} \mathrm{C}$ & 8.61 & 0.0262 & 0.098 & 0.9699 & 0.0858 & 0.4742 & 1.097 & 2.757 & 0.9602 & 0.0576 & 0.5436 \\
\hline $50^{\circ} \mathrm{C}$ & 6.39 & 0.0377 & 0.070 & 0.9680 & 0.0295 & 0.3099 & 1.299 & 3.522 & 0.9657 & 0.0292 & 0.3207 \\
\hline $60^{\circ} \mathrm{C}$ & 5.44 & 0.0730 & 0.037 & 0.9394 & 0.0340 & 0.3992 & 1.879 & 5.261 & 0.8189 & 0.1327 & 0.6682 \\
\hline
\end{tabular}

Table 3: Thermodynamic parameters for the adsorption of dye on orange peel adsorbent.

\begin{tabular}{|c|r|r|r|r|}
\hline \multirow{2}{*}{ Thermodynamic constant } & \multicolumn{4}{|c|}{ Temperature (K) } \\
\cline { 2 - 5 } & $\mathbf{3 0 3 . 1 5}$ & $\mathbf{3 1 3 . 1 5}$ & $\mathbf{3 2 3 . 1 5}$ & $\mathbf{3 3 3 . 1 5}$ \\
\hline $\mathrm{K}_{\mathrm{c}}$ & 340.8 & 485.9 & 696.0 & -144.0 \\
$\Delta \mathrm{G}^{\mathrm{o}}\left(\mathrm{kJ} \mathrm{mol}^{-1}\right)$ & -14.70 & -16.11 & -17.59 & -18.32 \\
$\Delta \mathrm{H}^{\mathrm{o}}\left(\mathrm{kJ} \mathrm{mol}^{-1}\right)$ & \multicolumn{3}{|c|}{22.82} \\
$\Delta \mathrm{S}^{\mathrm{o}}\left(\mathrm{J} \mathrm{mol}^{-1} \mathrm{~K}^{-1}\right)$ & \multicolumn{3}{|c|}{124.2} \\
\cline { 2 - 5 }
\end{tabular}


The thermodynamic parameters of the adsorption, i.e., the standard Gibbs free energy $\Delta \mathrm{G}^{\mathrm{o}}$, enthalpy $\Delta \mathrm{H}^{\circ}$ and entropy $\Delta \mathrm{S}^{\mathrm{o}}$, were calculated according to Equations (8) and (9).

$\Delta \mathrm{G}^{\mathrm{o}}=-\mathrm{RT} \ln \mathrm{K}_{\mathrm{c}}$

The slope and the intercept of the plots of $\operatorname{lnK}_{\mathrm{c}}$ versus $1 / \mathrm{T}$ were used to determine the $\Delta \mathrm{H}^{\circ}$ and $\Delta \mathrm{S}^{\mathrm{o}}$ values (Figure 8).

$\ln \mathrm{K}_{\mathrm{c}}=\frac{\Delta \mathrm{S}^{\mathrm{o}}}{\mathrm{R}}-\frac{\Delta \mathrm{H}^{\mathrm{o}}}{\mathrm{RT}}$

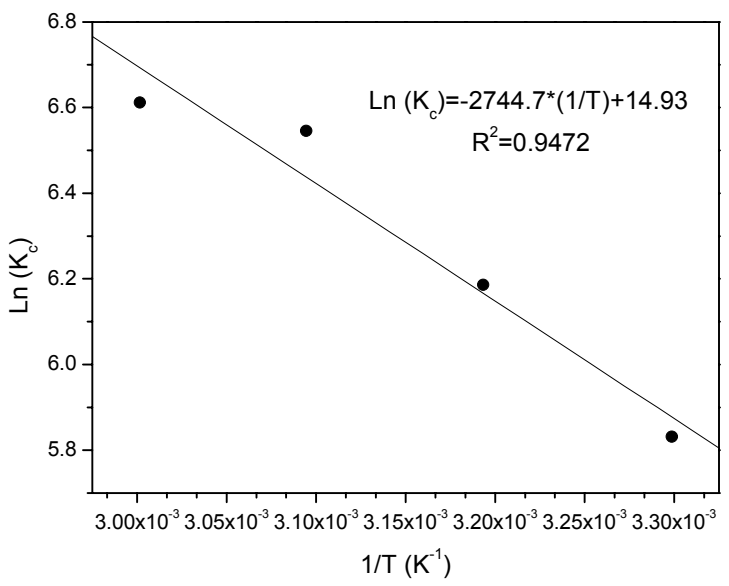

Figure 8: Van't Hoff plot of adsorption equilibrium constant Kc.

The free energy of the process at all temperatures was negative and changed with the rise in temperature (Table 3). This indicates that the adsorption process was spontaneous and thermodynamically favourable. The more negative values of $\Delta G^{\circ}$ imply a greater driving force for the adsorption process. As the temperature increased, the $\Delta \mathrm{G}^{\mathrm{o}}$ value increased, indicating a higher driving force resulting in a greater adsorption affinity at higher temperatures (Aman et al., 2008). The value of $\Delta \mathrm{H}^{\mathrm{o}}$ was positive, indicating that the adsorption process was endothermic in nature. The positive value of $\Delta \mathrm{S}^{\circ}$ suggested increased randomness at the solid/solution interface with some structural changes in the adsorbate and the adsorbent and an affinity of the adsorbent toward dye (Srivastava et al., 2006). Though the adsorption of dyes is currently described as an exothermic phenomenon (Jain et al., 2003; Iqbal and Ashiq, 2007), endothermic adsorption was also reported in the literature: acid orange 7 dye in aqueous solutions using spent brewery grains (Silva et al., 2004), methylene blue adsorption using wheat shells (Bulut and Aydin, 2006) and malachite green and basic red using activated carbon and activated slag (Gupta et al., 1997; Gupta et al., 2003). Iqbal and Ashiq (2007) reported $\Delta S^{\circ}$ negative values for the adsorption of the following dyes from aqueous solutions on activated carbon: alizarine red-S, methyl blue, methylene blue, eriochrome black-T, malachite green, phenol red and methyl violet, indicating that the randomness at the solid-solution interface decreased during adsorption. However in case of dye bromophenol blue, the entropy increased like in the present work and the same phenomenon was reported by Gupta et al. (1997), Gupta et al. (2003), Silva et al. (2004), Bulut and Aydin (2006) for others dyes. These differences may be attributed to the physical and chemical characteristics of the dyes and adsorbents, which play an important role in adsorption.

\section{CONCLUSIONS}

The results presented here show that orange peel is a promising and cheap adsorbent for the removal of the dye Remazol Brilliant Blue R. The OPA particle size distribution showed that $80.46 \%$ of the particles are in the range of 1,180-355 $\mu \mathrm{m}$. SEM micrographs of the adsorbent showed a highly heterogeneous surface and the X-ray diffraction spectrum revealed a completely amorphous structure. The experimental data indicated that the adsorption capacity was dependent on operating variables such as contact time, temperature and initial dye concentration. The contact time required to attain equilibrium was around $15 \mathrm{~h}$ for the three initial concentrations of dye studied ( $30 \mathrm{mg} \mathrm{L}^{-1}, 100 \mathrm{mg} \mathrm{L}^{-1}$ e $250 \mathrm{mg} \mathrm{L}^{-1}$ ). The adsorption obeyed both Langmuir and Freundlich isotherms. Regarding adsorption thermodynamics, negative values of $\Delta \mathrm{G}^{\mathrm{o}}$ indicated that the adsorption processes was favourable and, as the temperature increased, the $\Delta \mathrm{G}^{\mathrm{o}}$ value increased, indicating a higher driving force resulting in a greater adsorption affinity at higher temperatures. A positive value of $\Delta \mathrm{H}^{\circ}$ suggested an endothermic process and a positive value of $\Delta \mathrm{S}^{\circ}$ indicated that the solid/liquid interface was less ordered after adsorption.

\section{NOMENCLATURE}

$\begin{array}{lll}\Delta \mathrm{G}^{\mathrm{o}} & \begin{array}{l}\text { Standard Gibbs free energy } \\ \text { of adsorption }\end{array} & \mathrm{kJ} \mathrm{mol}^{-1} \\ \Delta \mathrm{H}^{\mathrm{o}} & \begin{array}{l}\text { Standard Enthalpy of } \\ \text { adsorption }\end{array} & \mathrm{kJ} \mathrm{mol}^{-1}\end{array}$




\begin{tabular}{|c|c|c|}
\hline 664 & M. R. Mafra, & Igarashi-Mafra, \\
\hline$\Delta \mathrm{S}^{\mathrm{o}}$ & $\begin{array}{l}\text { Standard Entropy of } \\
\text { adsorption }\end{array}$ & $\mathrm{J} \mathrm{mol}^{-1} \mathrm{~K}^{-1}$ \\
\hline $\mathrm{C}_{\mathrm{e}}$ & $\begin{array}{l}\text { Equilibrium liquid-phase } \\
\text { dye concentration }\end{array}$ & $\mathrm{mg} \mathrm{L}^{-1}$ \\
\hline $\mathrm{C}_{\mathrm{o}}$ & Initial dye concentration & $\mathrm{mg} \mathrm{L}^{-1}$ \\
\hline $\mathrm{C}_{\mathrm{t}}$ & $\begin{array}{l}\text { Liquid-phase concentration } \\
\text { of dye at time } \mathrm{t}(\mathrm{min})\end{array}$ & $\mathrm{mg} \mathrm{L}^{-1}$ \\
\hline FTIR & $\begin{array}{l}\text { Fourier transform infrared } \\
\text { spectroscopy }\end{array}$ & \\
\hline JCPDS & $\begin{array}{l}\text { Joint Committee on Powder } \\
\text { Diffraction Standards }\end{array}$ & \\
\hline $\mathrm{K}_{\mathrm{c}}$ & $\begin{array}{l}\text { Thermodynamic } \\
\text { equilibrium constant }\end{array}$ & \\
\hline $\mathrm{K}_{\mathrm{F}}$ & Freundlich constant & $\begin{array}{l}\left(\mathrm{mg} \mathrm{g}^{-1}\right) \\
\left(\mathrm{mg}^{-1}\right)^{1 / \mathrm{n}}\end{array}$ \\
\hline $\mathrm{K}_{\mathrm{L}}$ & Langmuir constant & $\mathrm{L} \mathrm{mg}^{-1}$ \\
\hline $\mathrm{n}$ & Freundlich constant & \\
\hline OPA & Orange peel adsorbent & \\
\hline $\mathrm{q}_{\mathrm{e}}$ & $\begin{array}{l}\text { Amount of dye adsorbed at } \\
\text { equilibrium }\end{array}$ & $\mathrm{mg} \mathrm{g}^{-1}$ \\
\hline $\mathrm{q}_{\max }$ & $\begin{array}{l}\text { Maximum adsorption } \\
\text { capacity }\end{array}$ & $\mathrm{mg} \mathrm{g}^{-1}$ \\
\hline $\mathrm{q}_{\mathrm{t}}$ & $\begin{array}{l}\text { Amount of dye adsorbed at } \\
\text { time } t\end{array}$ & $\mathrm{mg} \mathrm{g}^{-1}$ \\
\hline $\mathrm{R}^{2}$ & Coefficient of determination & \\
\hline $\mathrm{R}_{\mathrm{L}}$ & $\begin{array}{l}\text { Dimensionless constant- } \\
\text { separation factor }\end{array}$ & \\
\hline SD & Standard deviation & \\
\hline SEM & $\begin{array}{l}\text { Scanning electron } \\
\text { microscope }\end{array}$ & \\
\hline $\mathrm{t}$ & Time & $\min$ \\
\hline V & Solution volume & $\mathrm{L}$ \\
\hline $\mathrm{W}$ & Weight of the adsorbent & $\mathrm{g}$ \\
\hline XRD & $\mathrm{X}$-ray diffraction & \\
\hline $\mathrm{XRF}$ & $\mathrm{X}$-ray fluorescence & \\
\hline$\chi^{2}$ & Chi-square & \\
\hline
\end{tabular}

\section{REFERENCES}

Agrawal, A. and Sahu, K. K., Kinetic and isotherm studies of cadmium adsorption on manganese nodule residue. J. Hazard. Mater., B, 137, 915 (2006).

Al-Qodah, Z. and Shawabkah, R., Production and characterization of granular activated carbon from activated sludge. Braz. J. Chem. Eng. 26(1), 127 (2009).

Aman, T., Kazi, A. A., Sabri, M. U. and Bano, Q., Potato peels as solid waste for the removal of heavy metal copper (II) from wase water/ industrial effluent. Colloids Surf., 63, 116 (2008).

Annadurai, G., Juang, R.-S. and Lee, D.-J., Use of cellulose-based wastes for adsorption of dyes 
Iqbal, M. J., Ashiq, M. N., Adsorption of dyes from aqueous solutions on activated charcoal. J. Hazard. Mater., B, 139, 57 (2007).

Jain, A. K., Gupta, V. K., Bhatnagar, A., Suhas, Utilization of industrial waste products as adsorbents for the removal of dyes. J. Hazard. Mater., B, 101, 31 (2003).

Kalsi, P. S., Spectroscopy of Organic Compounds. Sixth Edition, New Delhi: New Age International (P) Ltda, p. 163 (2004).

${ }^{a}$ Khaled, A., El Nemr, A., El-Sikaily, A., Abdelwahab, O., Treatment of artificial textile dye effluent containing Direct Yellow 12 by orange peel carbon. Desalination, 238(1-3), 210 (2009).

${ }^{b}$ Khaled, A., El Nemr, A., El-Sikaily, A. and Abdelwahab, O., Removal of Direct N Blue-106 from artificial textile dye effluent using activated carbon from orange peel: Adsorption isotherm and kinetic studies. J. Hazard. Mater., 165, 100 (2009).

Khan, A. A., Singh, R. P., Adsorption thermodynamics of carbofuran on $\mathrm{Sn}(\mathrm{IV})$ arsenosilicate in $\mathrm{H}^{+}, \mathrm{Na}^{+}$ and $\mathrm{Ca}^{2+}$ forms. Colloids Surf., 24, 33 (1987).

Lyubchik, S. I., Lyubchik, A. I., Galushko, O. L., Tikhonova, L. P., Vital, J., Fonseca, I. M. and Lyubchik, S. B., Kinetics and thermodynamics of the $\mathrm{Cr}$ (III) adsorption on the activated carbon from co-mingled wastes. Colloids Surf., A, 164, 115-119 (2000).

Magdya, Y. H., Daifullah, A. A. M., Adsorption of a basic dye from aqueous solutions onto sugarindustry-mud in two modes of operations. Waste Management, 18, (4), 219 (1998).

Malik, P. K., Dye removal from wastewater using activated carbon developed from sawdust: Adsorption equilibrium and kinetics. J. Hazard. Mater., B, 113, 81 (2004).

Namasivayam, C. and Kavitha, D., Removal of congo red from water by adsorption onto activated carbon prepared from coir pith, an agricultural solid waste. Dyes Pigm., 54, 47 (2002).

Namasivayam, C., Muniasamy, N., Gayatri, K.,
Rani, M. and Ranganathan, K., Removal of dyes from aqueous solutions by cellulosic waste orange peel. Bioresour. Technol., 57, 37 (1996).

Nigam, P., Armour, G., Banat, I. M., Singh, D. and Marchant, R., Physical removal of textile dyes from effluents and solid-state fermentation of dye-adsorbed agricultural residues. Bioresour. Technol., 72, 219 (2000).

Niwas, R., Gupta, U., Khan, A. A., Varshney, K. G., The adsorption of phosphamidon on the surface of styrene supported zirconium (IV) tungstophosphate: A thermodynamic study. Colloids Surf., A, 164, 115 (2000).

Rao, V. V. B. and Rao, S. R. M., Adsorption studies on treatment of textile dyeing industrial effluent by flyash. Chem. Eng. J., 116, 77-84 (2006).

Silva, J. P., Sousa, S., Rodrigues, J., Antunes, H., Porter, J. J., Gonçalves, I., Ferreira-Dias, S., Adsorption of acid orange 7 dye in aqueous solutions by spent brewery grains. Sep. Purif. Technol., 40, 309 (2004).

Robinson, T., Chandran, P. and Nigam, P., Removal of dyes from a synthetic textile dye effluent by biosorption on apple pomace and wheat straw. Water Res., 36, 2824 (2001).

Robinson, T., McMullan, G., Marchant, R. and Nigam, P., Remediation of dyes in textile effluent: A critical review on current treatment technologies with a proposed alternative. Bioresour. Technol., 77, 247 (2001).

Sivaraj, R., Namasivayam, C. and Kadirvelu, K., Orange peel as an adsorbent in the removal of Acid violet 17 (acid dye) from aqueous solution. Waste Manage., 21, 105 (2001).

Srivastava, V. C., Swamy, M. M, Mall, I. D., Prasad, B., Mishra, I. M., Adsorptive removal of phenol by bagasse fly ash and activated carbon: Equilibrium, kinetics and thermodynamics. Colloid Surface, A, 272 (1-2), 89 (2006).

Yang, T. and Lua, J. A., Characteristics of activated carbons prepared from pistachio-nut shells by physical activation. Colloid Interface Sci., 267, 408 (2003). 